\title{
The Rise of China: A Threat to US Hegemony
}

\author{
Muhammad Fahim Khan \\ Ph D Scholar \\ Department of Political Science \\ University of Peshawar \\ Peshawar-Pakistan \\ fahimkhanjadoon86@gmail.com \\ Anwar Ali \\ Ph D Scholar \\ Department of Pakistan Studies \\ Abbottabad University of Science and Technology \\ Abbottabad - Pakistan \\ anwarswt@gmail.com \\ Dr. Hafiz Hammaduddin \\ Ph.D from Department of International Relations \\ FUUAST \\ Karachi-Pakistan \\ hafizhammaduddin@gmail.com
}

\begin{abstract}
In this article, there is a brief discussion on how the rising of China's state created a major threat for the United States Hegemony. According to Power Transition Theory (PTT), power is central in understanding the international system as a relative power to demonstrate the prerequisite for peace and war in the international system. So, power is basically an ability to impose on or convince a revolutionary act to comply with demands. The study is a qualitative analysis of the grounded facts and previously produced documents and researches. With the document analysis it is evident that both the countries work on the mutual interests, there is a low possibility of actual war like situation on any of the political or economic grounds between China and the US. China can be considered as an economic superpower if it peruse all its economic expansion plans, on the other hand US will remain on top on the political or military fronts.
\end{abstract}

Keywords: US China Trade, US Hegemony, Chinese Rise, 


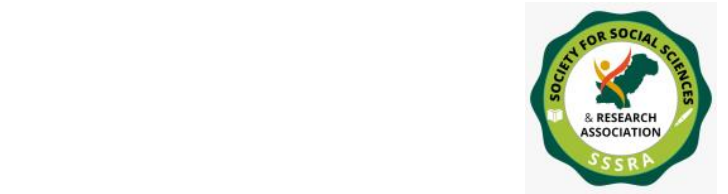

Pak. Journal of Int'L Affairs, Vol 4, Issue 3 (2021)

The Rise of China: A Threat to US ..

\section{Introduction}

For over half a century, the United States has been the dominant great power within the Asia-Pacific. Especially through alliance partnership and trade, the United States played a major role to shape the geopolitical and economic configuration of region. At the beginning of 1980s, the United States started engaged actively with China which itself begin a momentous turn towards trade-oriented development and market liberalization (Bello, 2012). No doubt, the United States provided a foundation for the cascade of economic and political transitions in East Asia. But, the rise of China state created a major threat for this nation, and it no longer becomes a great power within this region. It means this East Asian region is in a great transition to a new sort of order. (Ikenberry, 2014).

Like the extraordinary growth of Chinese economy with respect to active military and diplomacy buildup played a major role in the active transformation of this region (Zhang, 2004). When international relation's history is critically considered, then it becomes clear that from mid-1980s to late 1990s, there was a drastic change in Chinese economic growth like it grew approximately $10 \%$ a year. While, from 1990 s to 2005 , it grew at $8 \%$ to $9 \%$ annually. After this, in 2006 , more than $11 \%$ annual growth rate had been seen in the Chinese context (Layne, 2008). Such phenomenal economic growth of this state added value in its development as a major power. Also, such a similar pattern has been shown in international politics. Mostly the economic growth of a state grows at diverse rates which depicted that some nations always getting power and some losing power associated with others. In the book, "The Rise and Fall of the Great Powers", Paul Kennedy stated that time and again these relative economic shifts have "announced the rise of new great powers which one day would have a decisive impact on the territorial/ military order" (Kennedy \& Luttwak, 1990).

Many factors are involved in Chinese economic growth like the leadership in Beijing assimilates the link between economic force and geopolitical importance that directly add value to the sustainable growth of this nation. Such pre-planned strategic growth of this state, at both national and international levels, surpassed the United States as the world's largest economy (measured through gross domestic product). Well, the global hegemony (i.e. economic, political or military predominance or control of one state over all the others) now becomes the most frequently discussed and engaging topic of all political science (Kuo \& Yee, 2020). Like in the field of politics, it strived to explore the ideal form of international system, and how power should be assorted in the world. Between China and the United State, the hegemonic war's concept for global dominance has been specifically considered. Like the rising of China, as a global hegemonic status, is 


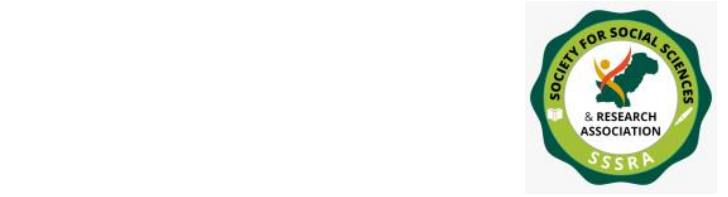

The Rise of China: A Threat to US ..

threatened by many to explore a radical shift in world affairs. There are crucial distinctions between its historical international systems and current system like the current digital market provides opportunities for all the states to flourish. Also, multilateralism played a major role in such differences.

Currently, international leadership is majorly dispersed between common capitalist states with the United States that caused a notion of system's overthrow to be far more complicated as compared to simply overcoming a single state. Like, an overthrow would require a complete convulsion of a base on which the collective group is dependent and flourish. Such an act not only entered China into a wholly unrealistic hegemonic war but also make it unnecessary to become an ornament of interdependent states, including the United States (Schiller, 2019). The liberal principles-based international laws have been prevailing that created equality of opportunity and economic mobility/ freedom. Such law created a threatening situation in front of US hegemony at international level. In current era, the cold war prevailing between both states i.e. China and the US in their trading and business activities. Also, one major challenge for the US is related to utilize new and old tools of administration ranging across strategies of both coercion and cooperation to manage China's rising (Tourangbam, 2017). At international level, the majority of developing and underdeveloped states aligned with "Washington" on security issues and "Beijing" on economic issues. China made many socio-economic projects that directly add value to its hegemonic growth i.e. Belt and Road Initiative-based mega project. Such aggressive projects of China pressurized the US in its international strategic growth.

\section{Literature Review}

The United States and China are battling an exchange war. Note that the trigger for an exchange battle between the world's two biggest economies is more political than monetary. In other words, as China's monetary and political impact on the planet builds contrasted with that of the United States, so does the American dread of China's power. Under these conditions, Washington bends over backward to combine its worldwide predominance by opposing the test of China's matchless quality. The "American dread" about the exchange of force from Washington to Beijing that has uncovered US approaches against the BRI, AIIB, and in China 2015 the exchange war started. Naturally, an exchange battle between the United States and China could be an antecedent to a lot bigger clash between the different sides. (Kim, 2019)

After the establishment of diplomatic relations between United States and China, the economic relations between the two countries has been growing rapidly, and the two countries are good partners in terms of imports and exports. The United States has 


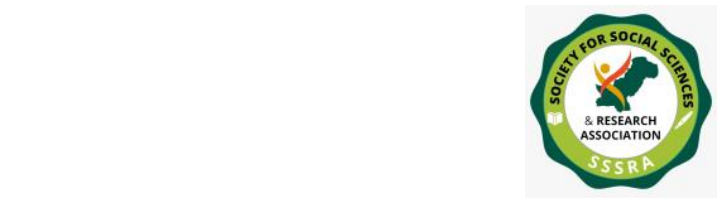

The Rise of China: A Threat to US ..

experienced a decade-long trade war with other European countries, but has never reached out to China. From an ideological point of view, the United States and China are looking at the world differently, embracing different cultures and, therefore, sharing different values. (Sider, 2020)

Although tensions between the United States and China are high, from trade wars to military tensions in the South China Sea, Sino-US relations are still characterized by mutual cooperation and strong economic interdependence, which are potentially difficult to resolve. Set up barriers Nevertheless, it is important to recognize that Sino-US relations appear to be at a crossroads due to both the Trump administration's rhetoric and policies that are integrated to isolate, control, and perhaps subjugate China. Seen as part of a strategy. (Nana de Graaff, 2020) The cost of membership of the liberal world community, for example, should be replaced by the demand for its official status as a "developing economy" and a "new developed economy".

\section{Chinese Economic Progress in the Chronicles}

After the World War II period, the 13 of the world's economy make their way towards the sustainability, by adopting few features to make them self above of all the common feature which these economies were adopting was their ability to tap the potential of the advantage of backwardness, in simple words, we can say that they were importing what the rest of the world knew and exported what it wanted. (Lin, 2010) China adopted this strategy and by 1979 Deng Xiaoping use this strategy and started to import what the rest of the world know and exporting what the world wants. This step brings rapid growth in its international trade and dependence ratio and increases the inflow of the world economy in their hands. Whatsoever. China makes its remarkable impact on the world by manufacturing cheap simple toys, textiles, and other products. Most of the essential household things are being imported from China.

China has a major influence on its economy, national bureau of Statistics stated that in 2014 China has achieved 7.5 percent of its economic growth. China has then adopted a policy where China makes itself separate from the organization's principles as other nations are doing now and started to hold industrial policies and state-owned enterprise and a techno-nationalism which help others to promote and protect the home-grown technologies. (Morrison, W. M., 2013)

China's economy has a massive growth rate from the late1990's, which is noted approximately 10 percent in a single year. And since then till 2005 their economy had annually growth of 8 percent to 9 percent, and in the following years their growth rate 


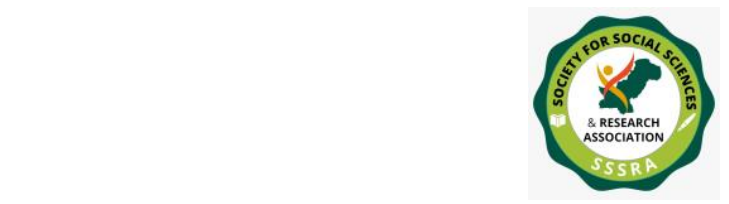

The Rise of China: A Threat to US ..

exceed to 10 percent to 11 percent. And in international politics a state's economic power growth rate has a variation by which they are more concern to change their ranks accordingly. The leadership understands the link between geopolitical weight and economical strengths and they realize that if China sustain to double digit growth rates in the early years of 21 st century than China will overshadow the place of U.S. and will become the world's largest economy. (Layne, 2008) Because they will produce more GWP than U.S.A journalist name James Kaynge said that in 2020 it is projected that China will become 1sr-rate military power in the world.

\section{Historical Analysis of US China Relations}

In the 19th to the 20th century during the transition, the United States became one of the most powerful state in the world. After the end of World War II in the mid-century, the United States emerged victorious and dominated every other nation on earth militarily and economically. The United States took Britain as its global patron, and in 1945 began playing a key role among state actors in managing world politics, building international institutions, and handling global governance. Many international relations experts, especially Paul Kennedy, suggest that 1945 was the beginning of an era in which the United States would emerge as a world leader and shape the international system. However, these intellectuals also theorize that the United States will eventually fall and lose its status as the supreme ruler of the world order. (Kapustina, L., Lipková, L', Silin, Y., \& Drevalev, A., 2020)

The initial of George W. Bush's first term suggested that US policy toward China was based on the need for military deterrence. Strengthening the US position on Taiwan, Bush called China a "strategic competitor" and claimed that the United States would do everything possible to help defend Taiwan. Bush's theory, described by Walter Russell Mead's "maximalist, bone-crushing" Jacksonism, said that "international order is a product of direct American importance." Increasing stability in the system with American power In short, challengers must be careful. President Bush's initial realistic pessimistic position, fearing Chinese expansion and favoring undisputed domination, is in line with John Mearsheimer's suggestion that the United States should cut China off its knees. (Jones, 2007) However, the events of September 11, 2001 changed the security environment in the United States, which significantly changed the dynamics of US-China relations. Overnight, realistic hope emerged, and China became a security cooperator, a useful ally and friend in the war on terror.

The global financial crisis in 2008 and 2009 can be seen as a game changer in this process. It demonstrated China's economic and political strength, especially with regard 


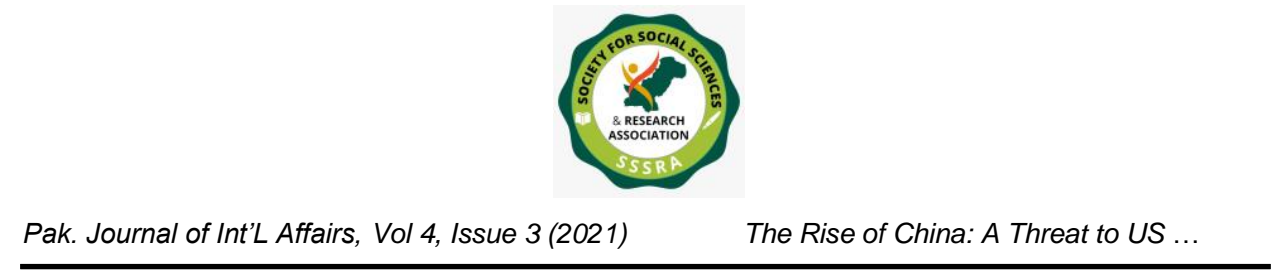

to the situation in the United States and Europe. After the crisis, China's expansion became stronger and the country became a net exporter of capital between 2014 and 2015. (Schutte, 2021) The capital's state-led exports focused not only on guaranteeing the supply of energy and raw materials, but also on the control of technical assets and the search for market opportunities.

The contemporary US-China exchange war isn't just the aftereffect of financial rubbing, however can likewise be deciphered as the two nations battling for global control, which called the Cold War. Despite the fact that there are a few similitudes between the Cold War and the Cold War between the United States and the Soviet Union, this is certifiably not a straightforward impersonation of the Cold War. As we probably are aware, during the Cold War, the two rival sides were totally isolated from one another militarily as well as monetarily and strategically. Their inclinations didn't cover. (SPOTLIGHT, 2018) Interestingly, China and the United States currently have normal interests in numerous spaces, which is the reason the opposition between the two nations is so intricate. That is the reason put "harmony" after "cold" to portray this element of the current US-China relationship.

\section{US China Trade Analysis}

The US and China have the best relation according to many other factors but trade is one of the elements between both countries which bring positive impact on them as well as other nations around the world. In 2020 China was the largest US goods trading partner with an estimated total trade of ( $\$ 659.5$ billion), the largest source of US imports, the third-largest US export market. In 2020 and 2018 in the same period, there is also a drastic fall in trade can be seen at almost 35\% between January and September in 2020 and 2018 both, making a large impact of loss for both parties. (Sutter, 2021)

China and U.S have hot, cold relations with each other, it is obvious that if both are competing on much of the stages so rivalry must be born. The rivalry between these two countries become more observed around 2 years ago in the area of strategic debates, military, weapon, power, and economic dynamic. The U.S China has a politically instrumental trade conflict. (O'Rourke, R. 2018) China is making its way to the top and above all, we can say that China and U.S have these issues which are because of being at the top.

\section{Contemporary Relations between US and China}




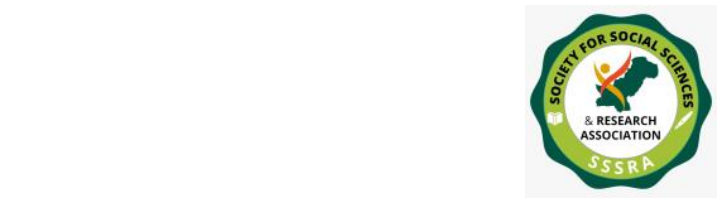

The Rise of China: A Threat to US ..

China will challenge the current regimes, the United States view, 'Transition' and 'succession' dominate this debate: China's rise affects the United States, which is IR scholars call it a 'power transition'. Effect Throughout the history of the modern international system of states, ascending. Powers have always challenged the position of the hegemonic power. The international system and these challenges usually end in war. The rise of China, we have been warned, will probably not be an exception. Whether peaceful or not, hegemonic transitions are definitely a recurring theme. Although many people question the extent to which this is already going on, However when examined closely, these changes seem to be nothing more than "global superiority". (Clark, 2011)

The results express that China's rise affects US economic dominance. Since 2001, the US trade deficit with China has grown significantly. The United States has become the world's first indebted country. However, the US dollar is the currency of international trade. In twenty years, the United States will become an influential country, but so will many influential countries in the multipolar world, as well as China. But the United States will not face the same situation as Britain did after World War II. China will see a slowdown in its economic growth (Nkounga, 2013) due to factors such as rising production costs, which could lead to domestic instability in Asia and the rest of the world with serious consequences.

Biden proposed the Built Back Better World B3W initiative for the United States and its G-7 partners. The White House issued a statement ahead of the G-7 summit setting targets, particularly a plan for access to finance and development assistance to help lowand middle-income countries build the necessary infrastructure projects. In this regard, the B3W proposal echoes China's efforts to enhance BRI and global connectivity. For now, details are unclear regarding B3W's financing and scope, but it is intended to be global and a concern for the United States and its allies, as well as shared values, standards, and climate change. (Holland, S., \& Faulconbridge, G., 2021)

\section{Chinese Rise in the Eyes of the World}

The rise of China is been the most indigestible event for the globe, we can say that China is one of the countries that is working to secure its spot in the Superpowers, and it can be seen that China is working on it rapidly and is showing its outcomes and result to the world and especially to the West, who consider themselves powerful. The Chinese economy is at their boom and we can say that they are already contributing themself to the east of Asia, by investing to help them to be better. (Ikenberry, 2008) We can assume by the current status that China will have a powerful future and can have the capability to 


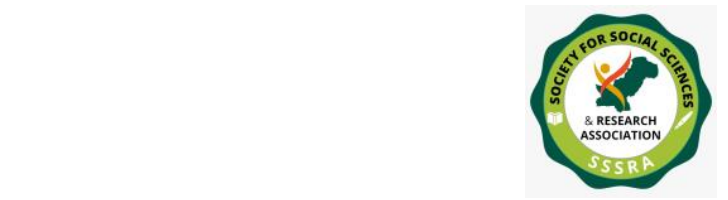

The Rise of China: A Threat to US ..

be the powerful and top country in the world. But by this is there any threat to the US is the major call for the people. (Xuetong, Y., 2006)

China has the vastest and advanced military forces in the world, China is budgeting a huge amount of capital towards its military and forces to make China the most secure and advance in forces. China is acquiring modern military weapons, equipment and from across the border. Instantly China is relied upon to twofold its atomic weapons inside 10 years and about 200 warheads ashore based intercontinental long range rockets. China likewise has halfway reach rocket capacity, they have supersonic journey rockets, current robots, and hypersonic weapons. As indicated by the research organization worldwide establishment for vital investigations, starting around 2014 China has acquired a bigger number of submarines and maritime boats than were right now serving the naval forces of Germany, India, Spain, Taiwan, and the United Kingdom. (Connolly, 2020)

\section{Threat Analysis in US China Relations}

The main pillar of United States hegemony which they pursue is their too vast military power, and for which they spend more than other countries spend on their military combine. (R. Posen, 2003) In 2003, the researchers said that US holds the superiority command on commons, command on the sea, Air, roads. According to us intelligence this command is because US has $23 \%$ of GWP (gross world product) and China just has $10 \%$ at that time. It means alone US was dominant by $13 \%$ by comparing with China.

China has made a massive impact on the U.S, and China's efforts to expand its growing influence acknowledge one of the largest threats to the United States. (Branes, 2021) There is no such military confrontation but it built up to the grey zones battles between them both and there are cold wars from the face of cyber-attacks, intensify with intelligence operation and global drives.

The hot topic for the world is that China is evolving day by day in the world and emerging as a new world power. Too many Asian countries are enjoying by the rapid growth of China because of their pattern of trade got changed and they avail benefits from them, Latin America is one of them which is facing threat by emerging of China, their relation is not just contain on trade but they've military and politically relation also. China has become the large exporter to Latin America, because the per hour labor cost in China is very low than Latin America and they have the advantage of cheap goods from China comparative to their own manufacture. And this is the main reason why China and Latin America relationship has been grown in past years. (Santibañes, 2009) China has invested highly in Latin America stock market which already shows the dominance of 


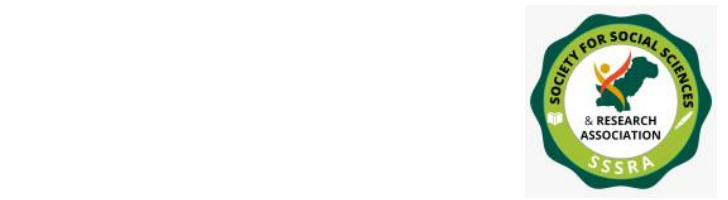

The Rise of China: A Threat to US ..

China in this region. This is the main reason that U.S. and China is already indulge in a cold war for the control of Latin America and this Is a serious threat to U.S. hegemony.

China is threating U.S. by many areas and the most recent examples are one belt road initiative, the creation of the AIIB, and the plan of Beijing "made in China 2025" etc., which are threating hegemony of U.S., But U.S. will not allow to over shadow them to any one and that's why they are taking serious measures against that issue, they are allying with several countries like Japan, India, Australia, and strengthening their relationship with them and many more countries and also trying to weaken the project of China by weaken their financial institution like IMF, world bank and Asia development bank because they are close ally to U.S. Japan has also helped US and give pressure to allies of China by not to agree to AIIB creation. (Kim, 2018) The US former president Trump also disagree of the made in China 2025 program because of various reasoning, but the real issue is that they are facing threats by China.

The future of China and the United States cannot be emphasized, because both the country is in their race for the top. Back then there are some ups and downs throughout the years. (Cinar, 2021) Beijing and Washington, the two largest economies in the world so for both countries it is necessary to bring stable relations. There is financial and commercial relation share between Beijing and Washington.

In China all rights are always granted by the Government personals according to the constitution of China 1980. Citizens have right for their rights at the time. Constitution of liberty in 1960 was lacking, which means there is still uncertainty for the rights, security and property for the citizen. By eliminating such uncertainty, they can bring more open opportunities in way that innovation and entrepreneurial opportunities will flourish and bring massive change in the country, by such practices there will be the inflow of trust among countries and RMB would become the major reserve currency. (Dorn, 2019) Both China and U.S have to respect and support the rules- based international trading regime.

China and the US are not having any war on the bigger level because they both can bring a much higher disaster to them and to other countries too. Cold war is the major medium of their back-and-forth rivalry actions. Cold war can will can make this nation not to fall because they both are incomparable due to their rapid economy a power growth. Through cyber internet, through electronic media they are making their ways to each other's ears and head.

\section{Future Prospects of US China Relations}




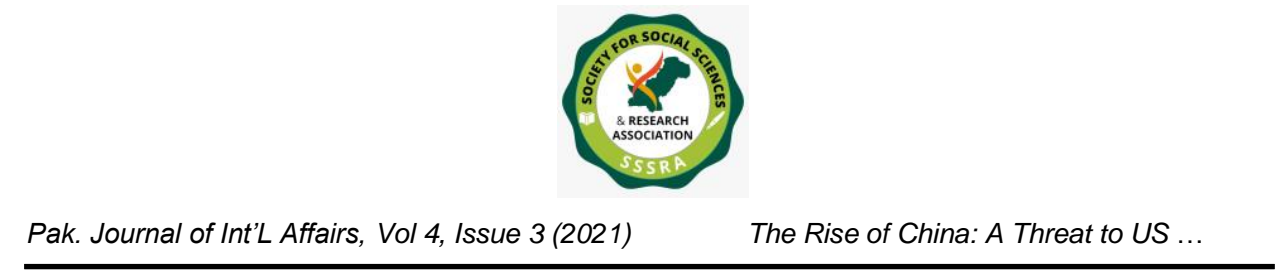

The people of China known that to overcome US is not a short term process, so they work for years to achieve this milestone they make short term plans along with short term plans, because they saw a massive disaster time in early and mid-19's, they know that in the current time they won't able to see China as emerging nation and a super power but rather they worked for their upcoming generations. (Xuetong, 2001)

China has investing in east Asia, after that those states builds a great relation with China and allying with Africa and Latin America too, China already replaced Japan and becomes the 2nd biggest economy in the world which threats U.S. the most, that is why US expended his military basis and alliances in east Asia too, (Adnan, 2014) they both are rivals but some time they both make strategic alliances for personal benefits too and nobody knows the result that in the end they both create war or peace.

After the rise of the covid, China has emerged as a new super power for the world, because US was not prepared for this challenge and China took the advantage of this gap, China was growing with a rapid speed. China overcome US by its manufacturing globally and leave the US on number two, (Schutte, 2021) but China is still an under developed country and that is the main advantage the U.S. has.

Since the double growth rate is not the main reason behind the rise of China or China will take over US in upcoming time, there are multiple opinions, some are with China and some are not, because straight line growth rate doesn't means US is in danger. (Layne, 2009) Many international scholars says that US will sustain its image in world politics with the help of their soft power, American free-market capitalism and, more generally, liberalism itself (economically and institutionally) are discredit by global financial and economic crisis. China has also its soft power and if it maintains his economic storm better than US, than will create an advantage on US. Because he is helping other under developed countries and gaining sympathy.

It has also been seen that US stand at the top in this fight in term of GDP (gross domestic product) or PPP (purchasing power parity) while China is $5 \$ 5$ trillion smaller than US in comparing. And not only that US has is the best military forces in terms of navy, air force globally which clearly indicates that US will remain the leader. (Herrington, 2011)

Studies to find who will be demonian on one another are shown that there are bias opinion on both the side some says that China and US both rule the world and other suggests that US has many advantages on different categories, so the question arise that it will remain same or not? does China will become a super power or not, Although China has narrowed most of the gaps to compete with US, in terms of GDP, exports , 


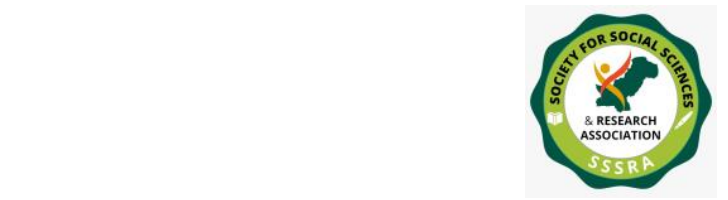

The Rise of China: A Threat to US ..

technological innovation and in every sector. (Beckley, 2011) And both the countries are facing many problems within them. So there is a long debate about that who will or win or what if they create the balance.

\section{Findings and Conclusion}

In this commentary, there is a concise conversation on how the ascending of China's state made a significant danger for the United States Hegemony. Be that as it may, the ascent of China state made a significant danger for this country, and it no longer turns into an incredible force inside this district. Among China and the United State, the authoritative conflict's idea for worldwide predominance has been explicitly thought of. Particularly through union association and exchange, the United States assumed a significant part to shape the international and financial arrangement of area. Such forceful tasks of China compressed the US in its worldwide vital development.

Generally the monetary development of a state develops at assorted rates which portrayed that a few countries continually getting force and some losing power related with others. China made numerous financial activities that straightforwardly enhance its domineering development for example like the ascending of China, as a worldwide domineering status, is compromised by numerous individuals to investigate an extreme change in world issues. After this, in 2006, over $11 \%$ yearly development rate had been found in the Chinese economy such marvelous monetary development of China added esteem in its advancement as a significant force. Such pre-arranged key development of this state, at both public and global levels, outperformed the United States as the world's biggest economy (estimated through total national output). Like, a defeat would require a total spasm of a base on which the aggregate gathering is reliant and thrive.

After the crisis, China's extension became more grounded and the nation turned into a net exporter of capital somewhere in the range of 2014 and 2015. It showed China's monetary and political strength, particularly as to the circumstance in the United States and Europe. In any case, the US dollar is the currency of worldwide exchange. Under these conditions, Washington bends over backward to solidify its worldwide predominance by opposing the test of China's incomparability. Be that as it may, the United States won't confront a similar circumstance as Britain did after World War II. The United States has encountered a very long term exchange battle with other European nations, however has never contacted China. In such manner, the $\mathrm{B} 3 \mathrm{~W}$ proposition echoes China's endeavors to upgrade BRI and worldwide network. 


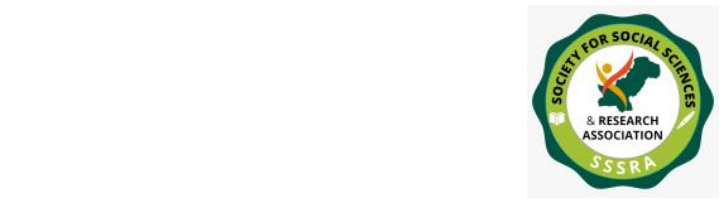

The Rise of China: A Threat to US ..

Biden proposed the Built Back Better World B3W drive for the United States and its G-7 accomplices. The outcomes express that China's ascent influences US monetary strength. Nonetheless, the occasions of September 11, 2001 changed the security climate in the United States, which altogether changed the elements of US-China relations. The United States and China are battling an exchange war. Reinforcing the US position on Taiwan, Bush considered China an "essential contender" and asserted that the United States would do all that could be within reach to assist with shielding Taiwan. The United States has become the world's first obliged country. Conversely, China and the United States presently have normal interests in numerous spaces, which is the reason the opposition between the two nations is so intricate. After the finish of World War II in the midcentury, the United States arose triumphant and overwhelmed each and every country on earth militarily and financially.

One of the extraordinary shows of the twenty-first century will without a doubt be China's development. This is particularly conceivable if a few of the world's best students of history and political researchers concur. In China's climb proceeds, it might turn into the world's most significant pattern for the following century. China's fast monetary extension and dynamic strategy are as of now reshaping East Asia, and Chinese force and impact will just fill in the coming many years. In any case, kindly help yourself out and watch the whole TED Talks video (connect underneath) China is on target to overwhelm the United States as the world's biggest economy, while India's economy could surpass China by 2050.

At the point when history specialists think back on our time in 100 years, they might conclude that the main advancement was the rise of a strong market economy and armed force on the planet's most crowded country. According to Martin Jacques, creator of "When China Rules the World: The Growth of the Middle Kingdom and The End of the Western World." We can't depict China's ascent utilizing Western originations" coming up next are Jacque's central issues. Moreover, in light of the fact that the Chinese public bookkeeping framework varies from that of most Western nations, it is hard to draw overall examinations. Regardless, such measures have dynamically raised concerns that China means to use mechanical procedures to lessen the country's reliance on new advancement (excluding by getting new firms China) and over the long haul overpower overall business areas. Will China agitate the set up demand? Regardless, how this show will play out stays not yet clear.

What's more, will turn into the world's biggest economy. What's more, this is the primary motivation behind why China and Latin America relationship has been filled in past years. Also, in worldwide legislative issues a state's monetary force development rate has 
a variety by which they are more worry to change their positions as needs be. China's economy has a gigantic development rate from the last part of the 1990's, which is noted around $10 \%$ in a solitary year. China has put exceptionally in Latin America securities exchange which as of now shows the predominance of China around here.

A writer name James Kanye said that in 2020 it is projected that China will become no. one military force on the planet. What's more, China is now enjoy a virus battle for the control of Latin America and this is a significant danger to U.S. The hotly debated issue for the world is that China is advancing step by step on the planet and arising as another force to be reckoned with. Furthermore, since than till 2005 their economy had yearly development of $8 \%$ to 9 percent, and before very long their development rate surpass to $10 \%$ to $11 \%$. The fundamental mainstay of United States authority which they seek after is to huge their tactical force, and for which they spend more than different nations spend on their tactical join. As per our knowledge this order is on the grounds that US has $23 \%$ of GWP (gross world product) and China simply has 10\% around then. 


\section{References}

Adnan, M. (2014). BRICS: A challenge to the US hegemony. Journal of Professional Research in Social Sciences, 1(1), 31-46.

Beckley, M. (2011). China's century? Why America's edge will endure. International Security, 36(3), 41-78.

Bello, M. (2012). China`s rise: Balancing the international system and the threat to US hegemony. Retrieved from Academia:

https://www.academia.edu/3709144/CHINAS_RISE_BALANCING_THE_INTE RNATIONAL_SYSTEM_AND_THE_THREAT_TO_US_HEGEMONY

Branes, J. E. (2021). China poses biggest threat to U.S., intelligence report says, The New York Times, Available at: https://www.nytimes.com/2021/04/13/us/politics/chinanational-security-intelligence-report.html

Cinar, A. (July 2021). The future of China-US relations, TRT World, Available at: https://www.trtworld.com/opinion/the-future-of-china-us-relations-48130

Clark, I. (2011). China and the United States: a succession of hegemonies?. International Affairs, 87(1), 13-28.

Connolly, G. E. (2020). The rise of China: Implication for Global and Euro-Atlantic Security, NATO Parliamentary Assembly, Draft General Report,

De Graaff, N., ten Brink, T., \& Parmar, I. (2020). China's rise in a liberal world order in transition-introduction to the FORUM. Review of International Political Economy, 27(2), 191-207.

De Santibañes, F. (2009). An end to US Hegemony? The strategic implications of China's growing presence in Latin America. Comparative Strategy, 28(1), 17-36.

Dorn, J. A. (2019). China's Future Development: Challenges and Opportunities. Cato $J ., 39,173$. 
Herrington, L. M. (2011). Why the rise of China will not lead to global hegemony. Academia, Avaiable at: https://www.academia.edu/1961362/Why_the_Rise_of_China_Will_Not_Lead_to _Global_Hegemony?from=cover_page

Holland, S., \& Faulconbridge, G. (2021). G7 rivals China with grand infrastructure plan. Reuters. https://www. reuters. com/world/g7-counter-chinas-belt-road-withinfrastructure-proj ect-senior-us-official-2021-06-12/(June 23, 2021).

Ikenberry, G. J. (2014). From hegemony to the balance of power: the rise of China and American grand strategy in East Asia. International Journal of Korean Unification Studies, 23(2), 41-63.

John Ikenberry, G. (2008). The rise of China and the future of the west. Foreign Affairs, 87(1), 23-37.

Jones, A. China's Rise and American Hegemony: Towards a Peaceful Co-Existence? EInternational Relations. Retried from https://www.e-ir.info/2007/12/22/chinasrise-and-american-hegemony-towards-a-peaceful-co-existence/

Kapustina, L., Lipková, L., Silin, Y., \& Drevalev, A. (2020). US-China trade war: Causes and outcomes. In SHS Web of Conferences (Vol. 73, p. 01012). EDP Sciences.

Kennedy, P., \& Luttwak, E. N. (1990). The rise and fall of the great powers: An exchange. The American Scholar, 59(2), 283-289.

Kim, M. H. (2019). A real driver of US-China trade conflict: The Sino-US competition for global hegemony and its implications for the future. International Trade, Politics and Development.

Kuo, K., \& Yee, W. Y. (August 2020). White privilege, American hegemony, and the rise of China. Retrieved from SupChina: https://supchina.com/2020/08/21/whiteprivilege-american-hegemony-and-the-rise-of-china/

Layne, C. (2008). China's challenge to US hegemony. Current History, 107(705), 13.

Lin, J. (2010, August). The China miracle demystified. In Econometric Society World Congress. 
The Rise of China: A Threat to US ...

Lippert, B., Perthes, V., \& und Politik-SWP-Deutsches, S. W. (2020). Strategic rivalry between United States and China: causes, tragectories, and implications for Europe.

Morrison, W. M. (2019). China's economic rise: history, trends, challenges, and implications for the United States, Current Politics and Economics of Northern and Western Asia; Hauppauge 28, 2/3,

Nkounga, F. J. (2013). The US economic hegemony and the rise of China: What lessons to be learned? Bachelor thesis in Political Science, Linnaeus University School of Social Sciences

O'Rourke, R. (2018). China's Actions in South and East China Seas: Implications for US Interests-Background and Issues for Congress. Page Congressional Research Service. Congressional Research Service.

Posen, B. R. (2003). Command of the commons: the military foundation of US hegemony. International security, 28(1), 5-46.

Schiller, L. (August 2019). Is hegemonic war with China inevitable? Medium.com. Retrieved from. https://medium.com/@lukasrhschiller/is-hegemonic-war-withchina-inevitable-7b34a1de3965

Schutte, G. R. (2021). revista Brasileira de Politica internacional . Retrieved from The challenge to US hegemony and the "Gilpin Dilemma": https://www.scielo.br/j/rbpi/a/BVS833gs8tBWChxBn3Y6HGM/?lang=en

Schutte, G. R. (2021). The challenge to US hegemony and the "Gilpin Dilemma". Revista Brasileira de Política Internacional, 64.

Sider, K. J. (2019). Sino-American Clash of Hegemony: An Analysis of US-China Trade War. Open Journal of Political Science, 10(1), 15-26.

SPOTLIGHT, J. (2018). Struggle for Global Hegemony-Real Implications of the ChinaUS Trade War. Japan Economic Foundation, Culture \& History JAPAN SPOTLIGHT Bimonthly, Available at: https://www.jri.co.jp/MediaLibrary/file/report/WuJunhua/pdf/10774.pdf 
Sutter, K. M. (2021). US-China trade and economic relations: Overview. Current Politics and Economics of Northern and Western Asia, 30(1), 87-93.

Tourangbam, M. (July 2017). Countering hegemony: The US-China balance. The Diplomat. Retrieved from. https://thediplomat.com/2017/07/counteringhegemony-the-us-china-balance/

Xuetong, Y. (2001). The rise of China in Chinese eyes. Journal of Contemporary China, 10(26), 33-39.

Xuetong, Y. (2006). The rise of China and its power status. The Chinese journal of international politics, 1(1), 5-33.

Zhang, B. (2004). American hegemony and China's US policy. Asian Perspective, 28(3), 87-113. 